\title{
Study on Use of Naked Barley (Hordeum vulgare var. Solu Uwa) Malt and Mold Bran as Enzyme Source for Preparation of Whisky DEV RAJ ACHARY** and BABITA ADHIKARI
}

\author{
Central Campus of Technology, Tribhuvan University, Dharan, Nepal
}

\begin{abstract}
Naked barley (Hordeum Vulgare L.) of Solu uwa variety having highest $\beta$-amylase activity (645 unit/gdm), total soluble solid and fermentable nitrogen germinated at $15{ }^{\circ} \mathrm{C}$ for $96 \mathrm{~h}$ and mold bran prepared from Aspergillus oryzae in wheat bran isolated from murcha having highest $\alpha$-amylase activity (904 unit $/ \mathrm{gdm}$ ) incubated at $30^{\circ} \mathrm{C}$ for $168 \mathrm{~h}$ were selected as enzyme source. Mold bran, naked barley malt and white maize flour (undertailed through $1.18 \times 1.18$ mesh size as substrate) were mixed to prepare four samples: 15\% naked barley malt $+85 \%$ maize flour (Sample A), 15\% mold bran $+85 \%$ maize flour (Sample B), $10 \%$ naked barley malt $+5 \%$ mold bran $+85 \%$ maize flour ( Sample C) and 5\% naked barley malt $+10 \%$ mold bran $+85 \%$ maize (Sample D). All samples were mashed separately to prepared wort, fermented using brewery yeast ( Saccharomyes cerevisiae) to prepare beer and distilled to prepare whisky and compared with wort, beer and whisky prepared from mixture of $15 \%$ commercial barley malt and 85\% maize flour ( Sample E). Total soluble solid, specific gravity, real extract, apparent extract, fusel oil, aldehyde, esters, titrable acidity, volatile acidity contents and sensory scores with respect to flavor, mouthfeel after taste and overall acceptability were significantly better $(p<0.05)$ in sample A than other samples $B, C$ and D but comparable with sample E whereas fermentable nitrogen, viscosity, alcohol, original extract contents and real degree of fermentation were found significantly better in sample B. However, sensory scores of samples were significantly lower $(p<0.05)$ in all samples than market whisky (Signature). Hence, without scarifying chemical and sensory scores sample D can be used to prepare whisky commercially. But harsh and pungent characteristics can be improved by maturation.
\end{abstract}

Keywords: Naked barley, Malt, Mold bran, Enzyme activity, Whisky

\section{Introduction}

Whisky is a beverage of high alcohol content made by distilling fermented mash of malted barley and other cereals (maize, rye, wheat, rice etc.) that has been fermented with Saccharomyces cerevisiae. It is called whisky in British and whiskey in US and Irish (Bathgate, 2003). It may be made from any mixture of grains, provided at least $51 \%$ of the total is accounted for by grain with which the finished product is identified (Prescott and Dunn, 1987). The most important ingredient from the standpoint of quality and function is barley malt (Stewart and Russell, 1987).

Naked barley is morphologically similar to barley, and they belong to same genus (Hordium) and species (Vulgare) (Harris, 1962). The only difference is that hull does not grow together with grain. Naked barley with a common name as Uwa in Nepal has several local names depending on ethnic group and region of cultivation. Naked barley of Nepal has tremendous amount of diversity with respect to adaptation and morphology. Diversity based on grain color and tear indicated the presence of about 14 distinct types of which eight were identified as eight botanical varieties (Sharma et al., 1994). Solu $u w a$ is one of the certified variety of naked barley by Nepal Agriculture Research Council Khumaltar, Kathmandu, Nepal (Khanal, 2008).

In the west, saccharification of cereals is achieved by using malt as a source of enzyme (amylase). In Asia the malting process is rarely used in traditional fermentation processes. Generally, fermentation starters prepared from the growth of

\footnotetext{
*Corresponding author, E-mail: devraj061@gmail.com
}

molds on raw or cooked cereals, called mold bran is more commonly practiced (Lee, 1999). In the Himalayan regions of India, Nepal, Bhutan, and Tibet (China), Marcha or murcha (traditional amylolytic starter) is used to produce sweet-sour alcoholic drinks, commonly called jand which contains saccharifying molds, lactic acid bacteria and fermenting yeasts which is used for isolation of mold, yeast and bacteria (Tsuyoshi et.al., 2005). Mold bran is an enzyme product obtained by growing Aspergillus oryzae or other mold on moist, sterilized bran. It is used successfully as a substitute for malt in the saccharification of grain, potato or other types of starch-containing mashes. By using different quantities of malt and mold bran as the saccharifying agents, yields of ethyl alcohol is high rather than using only malt (Prescott and Dunn, 1959). Therefore the objective of the study was to prepare whisky using different proportion of naked barley malt and mold bran as enzymee source and compared with whisky prepared from the commercial malt and market whisky.

\section{Materials and Methods}

Naked barley (Hordeum vulgare) of Solu Uwa variety was collected from National Hill Crop Research Center (NHCR), Dolakha, Nepal. Maize (Zea mays) of white variety and wheat bran were collected from local market of Dharan. Barley malt was collected from the Gorkha Brewery brewery yeast was collected from Songold brewery, Nawalparasi, Nepal. Pure cultures of Rhizopus oryzae and Aspergillus oryzae isolated from local Murcha were provided from the laboratory of Central Department of Food Technology (CDFT), Tribhuvan University, Dharan. Also, pure cultures of mold such as Aspergillus oryzae (ITCC 4855) and Rhizopus oryzae (ITCC 
4408) were collected from Division of Plant Pathology, Indian Agriculture Research Institute (IARI), New Delhi, India.

Preparation of naked barley malt- Seeds were winnowed and screened through a coarse and fine sieve to remove the impurities. Cleaned seeds were steeped for $12 \mathrm{hrs}$ at ambient temperature $\left(27^{\circ} \pm 2^{\circ} \mathrm{C}\right)$ and drained. The steeped grain was collected in muslin cloth and swirled in order to remove excess water. The grains were divided in three parts and spread over the plastic trays and covered with moistened muslin cloth and germinated at temperature of $15^{\circ}, 20^{\circ}$ and $30^{\circ} \mathrm{C}$ for five days. During germination the cereal was moistened by sprinkling water at $6 \mathrm{~h}$ of interval and mixed gently in order to equalize temperature and aerate the mass. Samples were taken at an interval of $24 \mathrm{hrs}$ at each temperature of germination and dried in a cabinet dryer in three stages: first stage at $50^{\circ} \mathrm{C}$ up to $23 \%$ moisture content; second stage at $70^{\circ} \mathrm{C}$ up to moisture content $12 \%$ and third stage at $90^{\circ} \mathrm{C}$ up to $3-5 \%$ moisture content. After drying the rootlets were removed and the prepared malt of each germination temperature was packed in airtight bottles separately.

Mold bran preparation- Mold culture Aspergillus oryzae, Aspergillus oryzae (ITCC 4855), Rhizopus oryzae and Rhizopus oryzae (ITCC 4408) were inoculated on PDA [potato dextrose agar with chloramphenical $(1.6 \mathrm{ml} / 400 \mathrm{ml})$ and rose Bengal $(0.5 \mathrm{ml} / 1000 \mathrm{ml})]$ media separately and incubated at $30 \pm 2^{\circ} \mathrm{C}$ and $90 \pm 5 \% \mathrm{RH}$ for 4 days. Then it was transferred into cold autoclaved wheat bran kept in a sterile conical flask. After mixing uniformly, flask was cotton plugged and covered externally with cold sterilized moistened muslin cloth and incubated at $30^{\circ} \mathrm{C}$. Thus prepared mold bran was taken out aseptically in every $24 \mathrm{~h}$ interval and broke the mycelia network and dried in Laboratory Electric Oven (UK) at d" $40^{\circ} \mathrm{C}$ for $12 \mathrm{hrs}$. Dried mold bran was packed separately in low density polyethylene (LDPE) and stored under refrigerated condition.

Methods of preparation of Whiskey-Naked barley malt, barley malt and Maize were ground separately in a grinder and flour passed through the screen of mesh size $1.18 \mathrm{~mm} \times 1.18 \mathrm{~mm}$ was taken. The samples were prepared in following proportions on the basis of dry matter.

Sample A: $15 \%$ naked barley malt $+85 \%$ maize flour

Sample B: $15 \%$ mold bran $+85 \%$ maize flour

Sample C: $10 \%$ naked barley malt flour $+5 \%$ mold bran + $85 \%$ maize flour

Sample D: $5 \%$ naked barley malt flour $+10 \%$ mold bran + $85 \%$ maize flour

Sample E: $15 \%$ commercial barley malt flour $+85 \%$ maize flour

Each sample was subjected for mashing separately.

Mashing was carried out in a stainless steel pot using flour of each sample A, B, C, D and E to water ratio of $1: 5(\mathrm{~m} / \mathrm{v})$ in the following sequence: First mash temperature increased to $45^{\circ} \mathrm{C}$ and held for $45 \mathrm{~min}, 60^{\circ} \mathrm{C}$ for $20 \mathrm{~min}, 65^{\circ} \mathrm{C}$ for $30 \mathrm{~min}$, $73^{\circ} \mathrm{C}$ for $15 \mathrm{~min}$ and finally increased upto $80^{\circ} \mathrm{C}$ and held for $10 \mathrm{~min}$ (mashing off period). After mashing, each mash was filtered through the muslin cloth of double fold and then the wort was subjected for fermentation in jar. The Brewery yeast (saccharomyces cerevisiae) was pitched at the rate of $100 \mathrm{ml} / 2 \mathrm{~L}\left(16 \times 10^{6} \mathrm{cfu} / \mathrm{ml}\right)$ wort into jars. Jars were cotton plugged and left for fermentation for 7 days at $28 \pm 2^{\circ} \mathrm{C}$. After fermentation, all the fermented mash were distilled separately in distillation unit under the same condition which were redistilled on the same set and the alcohol content of each distillate was adjusted about $40 \%$ (v/v \%).

Analytical procedure- Total acidities, volatile acidities and fixed acidities of the samples were determined as per the method described in Eagon et al., (2005) and the values were expressed as acetic acid as g per 100 liter absolute alcohol. Alcohol content was determined by dichromate oxidation method as per AOAC (2005) and the values were expressed as $\% \mathrm{v} / \mathrm{v}$. TSS of the samples was determined by using hand Refractometer. The values were expressed in ${ }^{\circ} \mathrm{Bx}$ (Pocket Refractometer MC, China) and values were corrected to $20^{\circ} \mathrm{C}$ as per Ranganna, (2001). Methanol and fusel oil contents of the samples were determined as per AOAC (2005) and the values were expressed as g per 100 liter absolute alcohol. Ester and aldehyde contents of the sample were determined as per Egon et al., (1981). The ester contents were expressed as g ester (as ethyl acetate) per 100 liter alcohol and the aldehyde as g acetaldehyde per 100 liter alcohol. Fermentable nitrogen was determined as per Zoecklein et al., (1997) and Gump, Zoecklein and Fugelsang (2002) and result was expressed as $\mathrm{mg}$ nitrogen per litre of wort. Viscosity of the samples were determined as per AOAC (2005). The values were expressed as centipoises (cP). Extract content of malt was determined as per AOAC (2005) after mashing and filtration of malt and values were expressed in percentage. Real extract, apparent extract and original extract were determined as per EBC, (1987).

Determination of enzyme activity- One gm of sample was grinded with 10 volume of distilled water at room temperature and filtered through the filter paper. The filtrate was used as enzyme source. Alpha and beta amylase activity were determined as per Mallik et al., (1980). Where one unit of $\alpha$-amylase activity was expressed as unit change in OD unit time at $37^{\circ} \mathrm{C}$ and one unit of $\beta$-amylase activity was expressed as one mg reducing sugar produced in 30 minutes at $30^{\circ} \mathrm{C}$.

Sensory evaluation- All Whisky samples were placed in conical flask and brought alcoholic strength $20 \% \mathrm{v} / \mathrm{v}$ with addition of distilled water and colored with caramel to maintain consistency, covered by watch glass and left for 30 minutes. Sensory evaluation was carried out using 9-point hedonic scale as per Rangana (2001). Nine semi-trained panelists consisting of administrative staffs, faculties and 
students of the college were ask to rate the acceptability of the product on a 9- point scale ranging from 1 ('dislike extremely') to 9 ('like extremely') in terms of color, flavor, mouth feel after taste and overall acceptability of the product.

Statistical analysis- The analyses were carried out in triplicate. Data were statistically processed by Analysis of Variance (ANOVA) using Genstat programming (Genstat Discovery Edition 3, 2010). Means of the data were compared using LSD (Least Significant Difference) method at 5\% level of significance.

\section{Results and Discussion}

Effect of germination condition on a-amylase activity of naked barley- Alpha-amylase activities of naked barley malt was determined and their mean values were given in Figure 1.

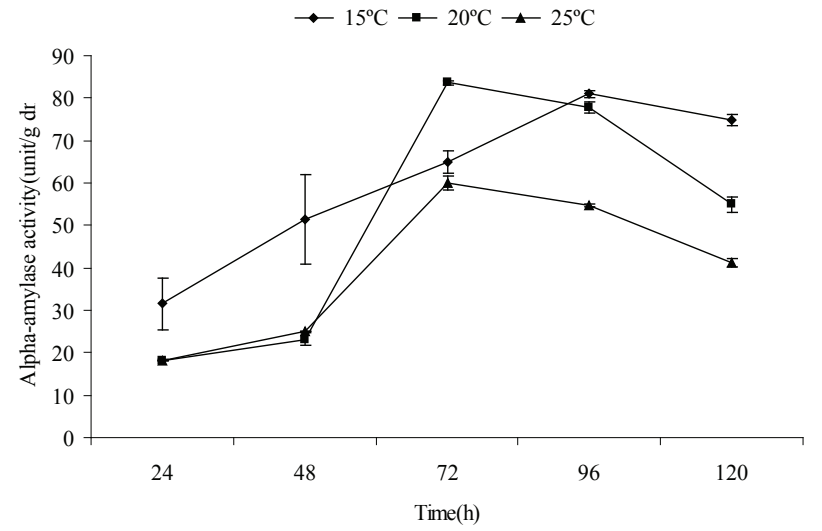

Figure 1. Effect of germination condition on $\alpha$-amylase activity of naked barley malt

Mean value of $\alpha$-amylase activity of Naked barley malt germinated at $15^{\circ} \mathrm{C}$ for $24,48,72,96$ and $120 \mathrm{~h}$ were found to be $31.56,51.43,64.87,80.97,74.85$ units per g dry matter respectively; at $20^{\circ} \mathrm{C}$ for $24,48,72,96$ and $120 \mathrm{~h}$ were found to be $18.23,23.17,83.68,77.84 .54 .91$ units per g dry matter respectively and at $25^{\circ} \mathrm{C}$ for $24,48,72,96$ and $120 \mathrm{hrs}$ were found to be $18.19,25.04,59.93,54.83 \& 41.23$ units per $g$ dry matter respectively.

Statistical analysis $(\mathrm{p}<0.05)$ showed that germination time and temperature had a significant effect on the $\alpha$-amylase activity of naked barley malt. At $15^{\circ} \mathrm{C}, \alpha$-amylase activity of malt was significantly increased $(\mathrm{p}<0.05)$ up-to $96 \mathrm{~h}$ germination and then decreased whereas at $20^{\circ}$ and $25^{\circ} \mathrm{C}$, it was significantly increased up-to 72 germination and then decreased. However, highest $\alpha$-amylase activity was found in malt germinated at $15^{\circ} \mathrm{C}$ for $96 \mathrm{~h}$ and $20^{\circ} \mathrm{C}$ for $72 \mathrm{hrs}$ which were significantly similar.

According to Tiwari (2010) $\alpha$-amylase activity of ACC\#523-1 variety of millet germinated at $30^{\circ} \mathrm{C}$ for 3 days was found to be highest and according Phiarais et al., (2005), $\alpha$-amylase activity of buckwheat germinated at $15^{\circ} \mathrm{C}$ for $96 \mathrm{~h}$ was found to be highest but those values were lower than that of naked barley malt. But values of $\alpha$-amylase activity of commercial barley malt reported by both were higher. Similarly, higher value reported by Goode et al., (2005).

Effect of germination condition on $\beta$-amylase activity of naked barley- Beta-amylase activities of naked barley malt was determined and their mean values were given in Figure 2.

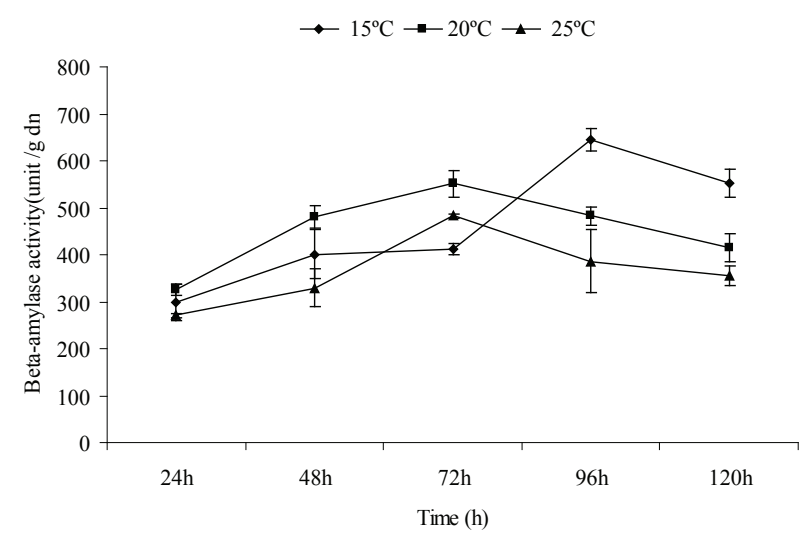

Figure 2. Effect of germination condition on $\beta$-amylase activity of naked barley malt

Mean value of $\beta$-amylase activity of naked barley malt germinated at $15^{\circ} \mathrm{C}$ for $24,48,72,96$ and $120 \mathrm{hrs}$ were found to be $298.6,401.4,412.3,645.0,552.6$ units per g dry matter respectively; at $20^{\circ} \mathrm{C}$ for $24,48,72,96$ and $120 \mathrm{hrs}$ were found to be $325.9,480.1,550.8,482.7,415.5$ units per $g$ dry matter respectively and at $25^{\circ} \mathrm{C}$ for $24,48,72,96$ and $120 \mathrm{hrs}$ were found to be $270.9,329.7,482.9,385.9 \& 355.7$ units per $g$ dry matter respectively.

Statistical analysis $(\mathrm{p}<0.05)$ showed that germination time and temperature had a significant effect on $\beta$-amylase activity. At $15^{\circ} \mathrm{C} \beta$-amylase activity of malt was significantly increased up to $96 \mathrm{hrs}$ germination and then decreased whereas at $20^{\circ}$ and $25^{\circ} \mathrm{C}$, it was significantly increased up to $72 \mathrm{hrs}$ germination and then decreased. However, highest $\beta$-amylase activity was found in malt germinated at $15^{\circ} \mathrm{C}$ for $96 \mathrm{hrs}$.

According to Tiwari (2010), $\beta$-amylase activity of ACC\#523-1 variety of millet germinated at $30^{\circ} \mathrm{C}$ for 3 days was found to be highest and according Phiarais et al., (2005), $\beta$-amylase activity of buckwheat germinated at $15^{\circ} \mathrm{C}$ for 96 hour was found to be highest but those values were lower than $\beta$-amylase activity of naked barley malt. Similarly, values of $\beta$-amylase activity of commercial barley malt reported by both were lower than that of naked barley malt but similar with that reported by Goode et al., (2005).

Effect of Incubation time on $\alpha$-amylase activity of mold branAlpha-amylase activities of mold prepared from Aspergillus oryzae and Rhizopus oryzae were determined and their mean values were given in Figure 3. 


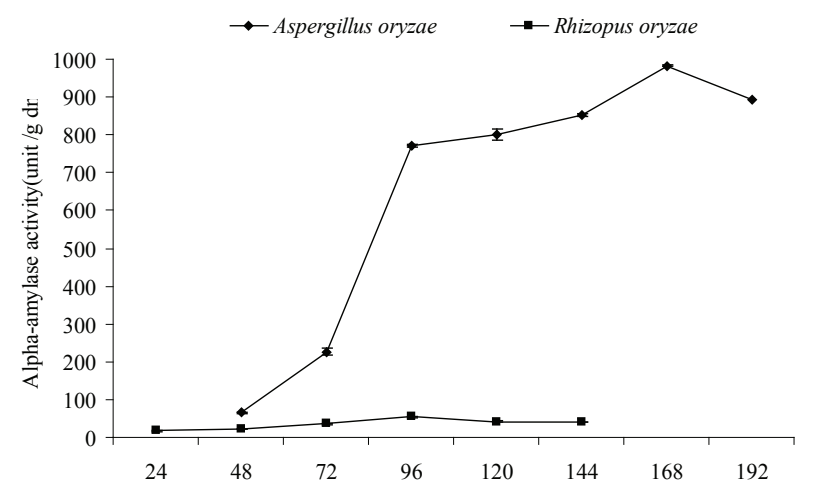

Figure 3. Effect of incubation time on $\alpha$-amylase activity of Mold bran

The mean value of $\alpha$-amylase activity of mold bran of Aspergillus oryzae incubated at $30^{\circ} \mathrm{C}$ for $48,72,96,120$, $144,168,192 \mathrm{~h}$ were found to be $65.17,226.7,769.82,801.81$, $853.16,982.82,894.62$ units per g dry matter respectively whereas $\alpha$-amylase activity of mold bran of Rhizopus oryzae incubated at $30^{\circ} \mathrm{C}$ for $24,48,72,96,120,144 \mathrm{hrs}$ were found to be $17.29,22.81,35.72,54.7,42.34,40.51$ units per $g$ dry matter respectively.

Statistical analysis $(\mathrm{p}<0.05)$ showed that incubation time had significant effect on $\alpha$-amylase activity of mold bran. In case of mold bran prepared from Aspergillus oryzae, $\alpha$-amylase activity significantly increased up to $168 \mathrm{hrs}$ incubation and then decreased whereas in case of Rhizopus oryzae, $\alpha$-amylase activity significantly increased up to $96 \mathrm{hrs}$ incubation and then decreased. However, highest $\alpha$-amylase activity was found in mold bran prepared from Aspergillus oryzae incubated at $30^{\circ} \mathrm{C}$ for $168 \mathrm{hrs}$.

Alpha-amylase activity of mold bran prepared from Aspergillus oryzae was 8 to 9 times higher than that of barley malt but in case of Rhizopus oryzae, value was nearly half than that of commercial barley malt. Also Corman and Langlykke (1948) reported that $\alpha$-amylase of mold culture filtrate was principal amylolytic enzyme which is related to malt $\alpha$-amylase for saccharification of starch.

\section{Effect of Incubation time on $\beta$-amylase activity of mold bran-}

Beta-amylase activities of mold prepared from Aspergillus oryzae and Rhizopus oryzae were determined and their mean values were given in Figure 4.

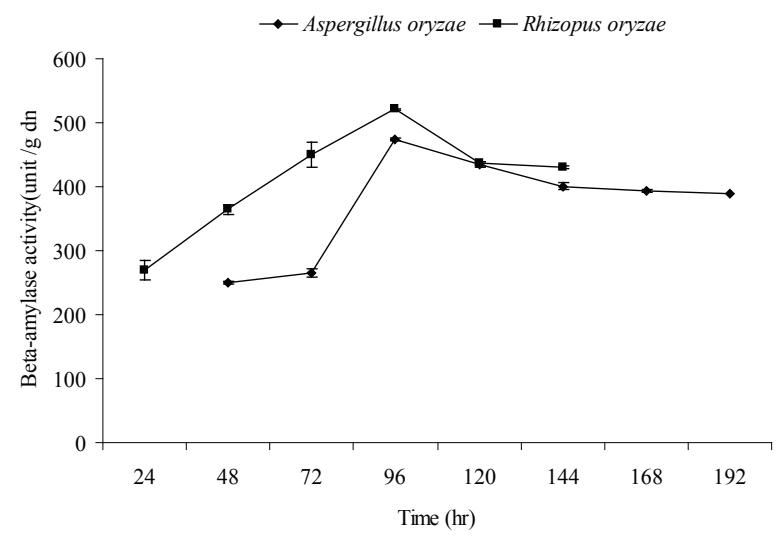

Figure 4. Effect of incubation time on $\beta$-amylase activity of Mold bran

The mean value of $\beta$-amylase activity of mold bran of Aspergillus oryzae incubated at $30^{\circ} \mathrm{C}$ for $48,72,96,120$, $144,168,192 \mathrm{hrs}$ were found to be $250.5,265.0,473.8,435.6$, $400.7,393.6,390.1$ units per $\mathrm{g}$ dry matter respectively whereas that of Rhizopus oryzae incubated at $30^{\circ} \mathrm{C}$ for $24,48,72,96$, 120 and $144 \mathrm{hrs}$ were found to be 269.5, 364.5, 449.8, 520.9, 436.4 , and 430.0 units per $g$ dry matter respectively.

Statistical analysis $(\mathrm{p}<0.05)$ showed that incubation time had significant effect on $\beta$-amylase activity of mold bran. Both Mold bran prepared from Aspergillus oryzae, and Rhizopus oryzae showed that $\beta$-amylase activity significantly increased upto $96 \mathrm{hrs}$ incubation and then remained significantly similar with increase in incubation time. However, highest $\beta$-amylase activity was found in mold bran prepared from Rhizopus oryzae incubated at $30^{\circ} \mathrm{C}$ for $96 \mathrm{hrs}$ which is similar with the $\beta$-amylase activity of commercial barley malt reported byTiwari (2010) and Phiarais et al., (2005) but lower than that reported by Goode et al., (2005).

Comparison of $\alpha$ and $\beta$-amylase activity of mold branMold bran prepared from Aspergillus oryzae, Aspergillus oryzae ITCC no. 4855 by incubating at $30^{\circ} \mathrm{C}$ for 168 hour and from Rhizopus oryzae, Rhizopus oryzae ITCC no. 4408 by incubating at $30^{\circ} \mathrm{C}$ for $96 \mathrm{hrs}$. Alpha and beta- amylase activities were determined and their mean values were given in Figure 5. 


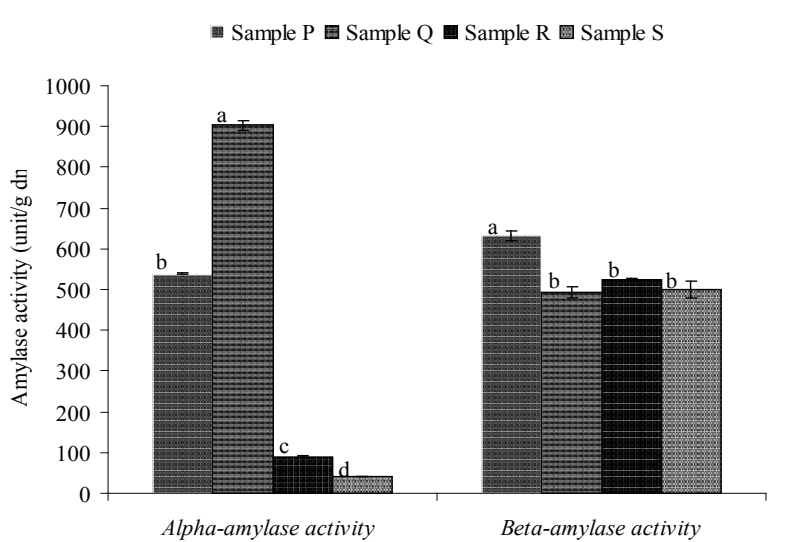

Figure 5. Comparision of $\alpha$ and $\beta$ - amylase activity of Mold bran

* Values in graph bearing the same superscripts are not significantly different $(\mathrm{p}<0.05)$; Sample P-Aspergillys oryzae ITCC no. 4855 collected from IARI, Sample Q- Aspergillus oryzae collected from CDFT, Sample R-Rhizopus oryzae ITCC no. 4408 collected from IARI and Sample S- Rhizopus oryzae collected from CDFT.
The mean value of $\alpha$-amylase activities of samples P, Q, R and $\mathrm{S}$ were found to be 539.4, 904, 90.4 and 41.2 units per gram dry matter whereas $\beta$-amylase activities were found to be $633.1,493,524.1498 .8$ units per gram dry matter respectively.

Statistical analysis $(\mathrm{p}<0.05)$ showed that $\alpha$-amylase activity significantly higher in sample Q but $\beta$-amylase activity was significantly higher in sample $\mathrm{P}$. While $\beta$-amylase activity of others samples Q, R and S were significantly similar. Corman and Langlykke (1948) reported that amylolytic activity of mold culture was principally due to $\alpha$-amylase. Hence, mold bran made from sample Q (Aspergillus oryzae from CDFT) was used for further study.

Chemical composition of commercial malt and naked barley malt-Beta-amylase activity of naked barley malt germinated at $15^{\circ} \mathrm{C}$ for $96 \mathrm{hrs}$ was found significantly higher than malt sample made from other germination time and temperature while $\alpha$-amylase activity was significantly similar between naked barley malt germinated at $15^{\circ} \mathrm{C}$ for $96 \mathrm{hrs}$ and $20^{\circ} \mathrm{C}$ for $72 \mathrm{hrs}$. Hence, both malts samples were subjected for chemical analysis. The mean chemical scores of samples and statistical analysis (ANOVA) for the scores were presented in Table 1.

Table 1. Chemical composition of commercial malt and naked barley malt

\begin{tabular}{|c|c|c|c|}
\hline Parameters & Sample X & Sample Y & Sample $\mathbf{Z}$ \\
\hline Specific gravity* & $1.06305^{\mathrm{a}}(0.0014)$ & $1.06207^{\mathrm{a}}(0.0013)$ & $1.05951^{\mathrm{a}}(0.001)$ \\
\hline TSS* & $16.03^{\mathrm{a}}(0.2)$ & $15.5^{\mathrm{b}}(0.1)$ & $14.66^{\mathrm{c}}(0.11)$ \\
\hline Viscosity* (cP) & $1.73^{\mathrm{b}}(0.07)$ & $4.02^{\mathrm{a}}(0.81)$ & $3.73^{\mathrm{a}}(0.7)$ \\
\hline Fermentable Nitrogen* (mg /1) & $246.75^{\mathrm{a}}(8.75)$ & $229.43^{b}(8.06)$ & $189.75^{\mathrm{c}}(2.5)$ \\
\hline$\alpha$-amylase activity (unit/gdm) & $97.72^{\mathrm{a}}(2.98)$ & $79.97^{\mathrm{c}}(0.24)$ & $83.85^{\mathrm{b}}(0.69)$ \\
\hline$\beta$-amylase activity (unit/gdm) & $564.95^{\mathrm{b}}(3.72)$ & $664.81^{\mathrm{a}}(19.79)$ & $534.96^{\mathrm{b}}(7.18)$ \\
\hline
\end{tabular}

*Values are the means of three determinations. Sample $X$-commercial barley malt, Sample $Y$ - naked barley malt germinated at $15^{\circ} \mathrm{C}$ for 96 hrs and Sample Z- naked barley malt germinated at $20^{\circ} \mathrm{C}$ for 72 hrs. Figures in parentheses are the standard deviations. Figures in the row bearing the same superscripts are not significantly different $(p<0.05)$. Parameters were determined in wort prepared from commercial malt, naked barley malt germinated at $15^{\circ} \mathrm{C}$ for $96 \mathrm{~h}$ and $20^{\circ} \mathrm{C}$ for $72 \mathrm{hrs}$. In which malt and water ratio was 1:5.

Statistical analysis $(\mathrm{p}<0.05)$ between samples $\mathrm{Y}$ and $\mathrm{Z}$ showed that TSS, fermentable nitrogen and $\beta$-amylase activity were significantly higher in sample $\mathrm{Y}$ and $\alpha$-amylase activity in sample $\mathrm{Z}$ but specific gravity, $\mathrm{pH}$, viscosity and percentage extract were significantly similar. Hence, important parameters for quality whisky production, sample Y (naked barley germinated at $15^{\circ} \mathrm{C}$ for 96 hour) was found better and selected for further study. However, TSS, fermentable nitrogen, percentage extract and $\alpha$-amylase activity were significantly lower in samples Y and Z than sample X. Similarly, except viscosity values of $\alpha$-amylase activity, $\beta$-amylase activity, percentage extract, fermentable nitrogen, viscosity, $\mathrm{pH}$ of barley malt reported by Phiaraise et al., (2005) and Wijagaard et al., (2005) were higher than corresponding values of samples $\mathrm{Y}$ and $\mathrm{Z}$ but those values of sample $\mathrm{Y}$ and $\mathrm{Z}$ were higher than the values of buckwheat.

Chemical composition of wort, beer and whisky- Thus, Mold bran (made from Apergillus oryzae by incubating at $30^{\circ} \mathrm{C}$ for 168 hour) and naked barley malt (made by germinating at $15^{\circ} \mathrm{C}$ for 96 hour), commercial barley malt and maize were used for preparation of samples A, B, C, D and E and subjected for preparation of wort, beer and whisky. The mean chemical scores of wort, beer and whisky of samples and statistical analysis (ANOVA) for the scores were presented in Table 2 and compared with market available signature whisky after distillation in laboratory. 
Table 2. Chemical composition of wort, beer and whisky

\begin{tabular}{|c|c|c|c|c|c|c|}
\hline & \multicolumn{6}{|c|}{ Wort } \\
\hline Parameter & Sample A & Sample B & Sample C & Sample D & Sample E & \\
\hline TSS & $14.73^{\mathrm{a}}(0.11)$ & $13.6^{\mathrm{c}}(0.25)$ & $14.2^{b}(0.2)$ & $13.6^{\mathrm{c}}(0.2)$ & $14.86^{\mathrm{a}}(0.3)$ & \\
\hline Specific gravity & $1.062^{\mathrm{a}}(0.005)$ & $1.054^{\mathrm{e}}(0.0001)$ & $1.056^{\mathrm{c}}(0.0001)$ & $1.055^{\mathrm{d}}(0.004)$ & $1.061^{\mathrm{b}}(0.0001)$ & \\
\hline $\begin{array}{l}\text { Fermentable } \\
\text { nitrogen }(\mathrm{mg} / \mathrm{l})\end{array}$ & $89.76^{\mathrm{d}}(0.51)$ & $289.26^{\mathrm{a}}(2.99)$ & $170.12^{\mathrm{c}}(0.1)$ & $256.33^{\mathrm{b}}(0.76)$ & $82.85^{\mathrm{d}}(2.35)$ & \\
\hline \multirow[t]{3}{*}{ Viscosity $(\mathrm{cP})$} & $1.69^{\mathrm{a}}(0.03)$ & $1.38^{\mathrm{e}}(0.015)$ & $1.49^{\mathrm{c}}(0.04)$ & $1.44^{\mathrm{d}}(0.021)$ & $1.56^{\mathrm{b}}(0.06)$ & \\
\hline & \multicolumn{6}{|c|}{ Beer } \\
\hline & Sample A & Sample B & Sample C & Sample D & Sample E & \\
\hline Alcohol $(\% \mathrm{v} / \mathrm{v})$ & $4.92^{\mathrm{C}}(0.09)$ & $5.82^{\mathrm{a}}(0.1)$ & $5.52^{b}(0.1)$ & $5.79^{\mathrm{a}}(0.07)$ & $4.97^{\mathrm{c}}(0.12)$ & \\
\hline Real extract (\%) & $3.63^{\mathrm{a}}(0.14)$ & $2.26^{\mathrm{e}}(0.05)$ & $2.46^{\mathrm{d}}(0.05)$ & $2.65^{\mathrm{c}}(0.045)$ & $3.23^{\mathrm{b}}(0.04)$ & \\
\hline $\begin{array}{l}\text { Apparent extract } \\
(\%)\end{array}$ & $3.28^{\mathrm{a}}(0.01)$ & $0.85^{\mathrm{e}}(0.035)$ & $1.54^{\mathrm{c}}(0.03)$ & $0.95^{\mathrm{d}}(0.02)$ & $3.17^{\mathrm{b}}(0.05)$ & \\
\hline $\begin{array}{l}\text { Original extract } \\
(\%)\end{array}$ & $14.58^{\mathrm{d}}(0.1)$ & $16.36^{\mathrm{a}}(0.045)$ & $15.54^{\mathrm{b}}(0.025)$ & $16.42^{\mathrm{a}}(0.045)$ & $14.82^{\mathrm{c}}(0.04)$ & \\
\hline \multirow{3}{*}{$\begin{array}{l}\text { Real degree of } \\
\text { fermentation }(\%)\end{array}$} & $80.61^{\mathrm{c}}(0.28)$ & $86.63^{\mathrm{a}}(0.09)$ & $85.44^{\mathrm{b}}(0.04)$ & $86.43^{\mathrm{a}}(0.086)$ & $80.25^{\mathrm{d}}(0.1)$ & \\
\hline & \multicolumn{6}{|c|}{ Whisky (g/100L absolute alcohol; acidity as acetic acid) } \\
\hline & Sample A & Sample B & Sample C & Sample D & Sample E & Sample F \\
\hline Fusel oil & $255^{\mathrm{a}}(20.36)$ & $154.9^{\mathrm{d}}(7.31)$ & $183.63^{\mathrm{bc}}(11.18)$ & $158.2^{\text {cd }}(23.79)$ & $194.23^{b}(3.77)$ & $75.24^{\mathrm{e}}(4.77)$ \\
\hline Methanol & $5.21^{\mathrm{ab}}(0.17)$ & $3.89^{\mathrm{c}}(0.3)$ & $4.61^{\mathrm{bc}}(0.14)$ & $4.51^{\mathrm{bc}}(0.22)$ & $5.39^{\mathrm{a}}(0.62)$ & $2.54^{\mathrm{d}}(0.5)$ \\
\hline Aldehyde & $82.93^{\mathrm{a}}(0.56)$ & $34.67^{\mathrm{e}}(1.62)$ & $64.7^{\mathrm{c}}(1.59)$ & $57.01^{\mathrm{d}}(0.98)$ & $71.76^{\mathrm{b}}(3.08)$ & $14.24^{\mathrm{t}}(3.17)$ \\
\hline Esters & $222.84^{\mathrm{a}}(30.66)$ & $154.64^{\mathrm{c}}(6.35)$ & $186.88^{\mathrm{b}}(14.78)$ & $163.04^{\mathrm{bc}}(9.34)$ & $190.25^{b}(5.1)$ & $52.49^{\mathrm{d}}(3.73)$ \\
\hline Titrable acidity & $109.12^{\mathrm{cd}}(5.07)$ & $132.43^{\mathrm{a}}(0.57)$ & $115.73^{\mathrm{c}}(2.36)$ & $123.02^{\mathrm{b}}(3.46)$ & $108.4^{\mathrm{d}}(6.43)$ & $7.49^{\mathrm{e}}(0.82)$ \\
\hline Fixed acidity & $6.8^{\mathrm{a}}(1.15)$ & $5.66^{\mathrm{a}}(0.73)$ & $6.12^{\mathrm{a}}(1.92)$ & $5.84^{\mathrm{a}}(0.14)$ & $6^{\mathrm{a}}(1.41)$ & $0.68^{\mathrm{b}}(0.03)$ \\
\hline Volatile acidity & $102.32^{\mathrm{d}}(4.6)$ & $126.76^{\mathrm{a}}(0.16)$ & $109.61^{\mathrm{c}}(0.44)$ & $117.17^{b}(3.47)$ & $102.4^{\mathrm{d}}(7.84)$ & $6.81^{\mathrm{e}}(0.81)$ \\
\hline
\end{tabular}

In terms of superiority ( at 5\% level of significance) of the wort of samples A, B, C, D and E with respect to TSS, specific gravity, $\mathrm{pH}$, fermentable nitrogen and viscosity, following conclusion were drawn:

TSS

Specific Gravity

$\mathrm{pH}$

$:[\mathrm{A} / \mathrm{E}]>[\mathrm{C}]>[\mathrm{B} / \mathrm{D}]$

Fermentable nitrogen

$:[\mathrm{A}]>[\mathrm{E}]>[\mathrm{C}]>[\mathrm{D}]>[\mathrm{B}]$

$:[\mathrm{B}]>[\mathrm{D}]>[\mathrm{C}]>[\mathrm{E}]>[\mathrm{A}]$

$:[\mathrm{B}]>[\mathrm{D}]>[\mathrm{C}]>[\mathrm{E}]>[\mathrm{A}]$

Viscosity

$:[\mathrm{A}]>[\mathrm{E}]>[\mathrm{C}]>[\mathrm{D}]>[\mathrm{B}]$

In terms of superiority (at 5\% level of significance) of beer of samples of A, B, C, D and E with respect to alcohol, real extract, apparent extract, original extract and real degree of fermentation, following conclusion were drawn:

Alcohol

Real extract

Apparent extract

$:[\mathrm{B} / \mathrm{D}]>[\mathrm{C}]>[\mathrm{A} / \mathrm{E}]$

Original extract

$:[\mathrm{A}]>[\mathrm{E}]>[\mathrm{D}]>[\mathrm{B}]>[\mathrm{C}]$

Real degree of fert

$:[\mathrm{A}]>[\mathrm{E}]>[\mathrm{C}]>[\mathrm{D}]>[\mathrm{B}]$

$:[\mathrm{B} / \mathrm{D}]>[\mathrm{C}]>[\mathrm{E}]>[\mathrm{A}]$

$:[\mathrm{B} / \mathrm{D}]>[\mathrm{C}]>[\mathrm{A}]>[\mathrm{E}]$

In terms of superiority (at 5\% level of significance) of whisky of samples of A, B, C, D, E and F with respect to fusel oil, methanol, aldehyde, ester, titrable acidity, fixed acidity and volatile acidity, following conclusion were drawn:

Fusel oil

Methanol

$:[\mathrm{A}]>[\mathrm{E} / \mathrm{C}]>[\mathrm{C} / \mathrm{D}]>[\mathrm{D} / \mathrm{B}]>[\mathrm{F}]$

Aldehyde

Ester

A $/ \mathrm{E}]>[\mathrm{A} / \mathrm{C} / \mathrm{D}]>[\mathrm{C} / \mathrm{D} / \mathrm{B}]>[\mathrm{F}]$

Titrable acidity

$:[\mathrm{A}]>[\mathrm{E}]>[\mathrm{C}]>[\mathrm{D}]>[\mathrm{B}]>[\mathrm{F}]$

Fixed acidity

$:[\mathrm{A}]>[\mathrm{E} / \mathrm{C} / \mathrm{D}]>[\mathrm{D} / \mathrm{B}]>[\mathrm{F}]$

Volatile acidity

$:[\mathrm{B}]>[\mathrm{D}]>[\mathrm{C} / \mathrm{A}]>[\mathrm{A} / \mathrm{E}]>[\mathrm{F}]$

$:[\mathrm{A} / \mathrm{B} / \mathrm{C} / \mathrm{D} / \mathrm{E}]>[\mathrm{F}]$

$:[\mathrm{B}]>[\mathrm{D}]>[\mathrm{C}]>[\mathrm{E} / \mathrm{A}]>[\mathrm{F}] \mathrm{o}$ :

Similar results with respect to $\mathrm{pH}$, TSS, alcohol content, real extract, apparent extract, original extract were reported by Acharya (2008) and Khanal (2008) whereas with respect to esters, methanol, fusel oil, aldehyde, titrable acidity and volatile acidity of Canadian whisky ( $>80$ maize used) were reported Prescott and Dunn (1987).

Besides TSS, fermentable nitrogen was significantly higher in sample B. Consequently, alcohol content was significantly high which may be due to significantly better original extract, real degree of fermentation and lower real extract. According to Munroe (2006), apparent extract always lower than real 
extract. Similarly all whiskies contain lower percentage extract than real extract. Viscosity was found significantly low in sample B because mold bran used as source of enzyme contains high $\alpha$-amylase activity. The decrease in alcohol content in sample A might have been attributed to the increase in ester and aldehyde contents at the expense of alcohol. Also, high ester may be contributed by low acidity of sample A due to its conversion. Fusel oil of sample A was found high which may be produced by yeast as secondary metabolites of amino acid metabolism of naked barley malt. According to Ayloh (2003), relatively low methanol concentration encountered in all whiskies fermented from cereals (normally $<25 \mathrm{~g} / 100 \mathrm{~L}$ absolute alcohol). So, all whiskies were found low in methanol content. Also, all chemical scores of sample E were found near to sample A but that of sample F were significantly lower than other samples. Hence, as the proportion of naked barley malt was increased TSS, specific gravity, fusel oil, aldehyde, ester, titrable acidity and volatile acidity were found better whereas the proportion of mold bran was increased viscosity, alcohol content, real extract, apparent extract, original extract, real degree of fermentation were found better.

Sensory evaluation of whisky- The mean sensory scores of whiskies made from samples A, B, C, D, E and market available signature whisky (sample $\mathrm{F}$ ) and statistical analysis (ANOVA) for the scores were presented in Table 3.

Table 3. Sensory evaluation of whisky

\begin{tabular}{lllllll}
\hline Parameter & Sample A & Sample B & Sample C & Sample D & Sample E & Sample F \\
\hline Color & $7.3^{\mathrm{a}}(0.82)$ & $6.9^{\mathrm{a}}(0.73)$ & $7^{\mathrm{a}}(1.05)$ & $6.9^{\mathrm{a}}(0.87)$ & $6.9^{\mathrm{a}}(1.28)$ & $7.2^{\mathrm{a}}(0.63)$ \\
Flavor & $6.9^{\mathrm{b}}(0.74)$ & $5.6^{\mathrm{d}}(0.69)$ & $6.3^{\mathrm{bc}}(0.48)$ & $6^{\mathrm{cd}}(0.81)$ & $6.8^{\mathrm{b}}(0.63)$ & $8.4^{\mathrm{a}}(0.69)$ \\
$\begin{array}{l}\text { Mouth feel } \\
\text { after taste }\end{array}$ & $6.7^{\mathrm{b}}(0.82)$ & $5.8^{\mathrm{c}}(1.03)$ & $6.2^{\mathrm{bc}}(0.78)$ & $5.9^{\mathrm{c}}(0.87)$ & $6.7^{\mathrm{b}}(0.67)$ & $8^{\mathrm{a}}(0.47)$ \\
$\begin{array}{l}\text { Overall } \\
\text { acceptability }\end{array}$ & $6.8^{\mathrm{b}}(0.63)$ & $6^{\mathrm{c}}(1.25)$ & $6.4^{\mathrm{bc}}(0.51)$ & $6.2^{\mathrm{bc}}(1.03)$ & $6.8^{\mathrm{b}}(0.79)$ & $8.1^{\mathrm{a}}(0.56)$
\end{tabular}

Values are the means of three determinations. Figures in parentheses are the standard deviations and the row bearing the same superscripts are not significantly different $(p<0.05)$.

In terms of superiority (at $5 \%$ level of significance) of whiskies of samples of A, B, C, D, E and F with respect to color, flavor, mouth feel after taste and overall acceptability, following conclusion were drawn:

Color

Flavor

Mouth feel after taste

Overall acceptability

$$
\begin{aligned}
& :[\mathrm{A} / \mathrm{B} / \mathrm{C} / \mathrm{D} / \mathrm{E} / \mathrm{F}] \\
& :[\mathrm{F}]>[\mathrm{A} / \mathrm{C} / \mathrm{E}]>[\mathrm{C} / \mathrm{D}]>[\mathrm{B} / \mathrm{D}] \\
& :[\mathrm{F}]>[\mathrm{A} / \mathrm{C} / \mathrm{E}]>[\mathrm{B} / \mathrm{C} / \mathrm{D}] \\
& :[\mathrm{F}]>[\mathrm{A} / \mathrm{C} / \mathrm{D} / \mathrm{E}]>[\mathrm{B} / \mathrm{C} / \mathrm{D}]
\end{aligned}
$$

All sensory scores of samples A, C and E were significantly similar with each other and higher than that of samples B and D. Hence as the proportion of naked barley malt increased it scored higher sensory value whereas proportion of mold bran increased it scored lower sensory value which may be due to lower fusel oil, acetaldehyde, ester and higher titrable and volatile acidities. Also, sample B showed moldy flavor. But sensory score of sample F were significantly better than other samples which may be due to flavor of grain, mold and alcohol of newly distilled whiskies. According to Ayloh (2003), if whisky (newly distillate) were matured addition, reduction and production of congeners at molecular level takes place so that pungent and harsh characteristics of new make whisky diminish and the smoother more complex character of mature whisky develops. Hence, sensory scores of young whisky can be increased.

\section{Conclusion}

Naked barley malt (germinated at $15^{\circ} \mathrm{C}$ for 96 hour) containing high $\beta$-amylase activity, TSS and fermentable nitrogen and mold bran (Aspergillus oryzae incubated at $30^{\circ} \mathrm{C}$ for 168 hour) having high $\alpha$-amylase activity were selected and mixed in different proportion as enzyme source for saccharification of white maize. Fermentable nitrogen, viscosity, alcohol, original extract and real degree of fermentation were found better in wort and beer made from flour mixture containing $15 \%$ mold $+85 \%$ maize whereas real extract, apparent extract, fusel oil, acetaldehyde, ester, titrable acidity, volatile acidity and sensory scores with respect to flavor, mouth feel after taste, overall acceptability were found significantly better in whisky made from flour mixture containing $15 \%$ naked barley malt $+85 \%$ maize. Hence, without sacrificing chemical and sensory scores whisky made from flour mixture made from $5 \%$ naked barley malt $+10 \%$ mold bran $+85 \%$ maize can be used but sensory attributes can be improved by maturation of new distillate whisky.

\section{References}

Acharya D. R. (2008). Study on brewing quality of naked barley (Hordeum vulgare L.). J. Food Sci. and Technol., $5,47-51$.

AOAC (2005). Official Method of Analysis. Part 27, AOAC International Suite 500481 North Frederick, Avenue. Gaithersburg, Maryland 20877-2417, USA.

Ayloh R. (2003). Whisky analysis. In: Whisky Technology, Production and Marketing, (I. Russell, G. Stewart and C. Bamforth eds.), pp. 174, 284-286, Academic press, USA. 
Bathgate G. N. (2003). History of the development of whiskey distillation. In: Whisky Technology, Production and Marketing (I. Russell, G. Stewart and C. Bamforth eds.), pp. 1, 2, Academic press, USA.

Corman A. and Langlykke P. (1948). Mold bran. In: Industrial Microbiology (S.C. Prescott and C.G Dunn eds.), McGraw-Hill Book Company, Inc. Newyork Toronto, London.

Egan H., Krik R. and Sawyer R. (1981). Pearson's Chemical Analysis of Foods, 8th edn., p.364-371, Churchill Livingstone, NewYork.

Goode D. L., Wijngaard H. H. and Arendt E. K. (2005). Mashing with unmalted barley-impact of malted barley and commercial enzyme (Bacillus spp.) addition. J. Am. Brew. Chem., 42, 184-198

Harris G. (1962). Barley and Malt (ed. Cook, A.H.) Academic press London. pp. 431, 583.

Khanal H. (2008). Study on the brewing quality of naked barley (Hordeum vulgare, var. Solu uwa), M.Tech.(food) dissertation ,CCT, Dharan, T.U., Nepal.

Lee C. H. (1999). Cereal Fermentation in Countries of the Asia-Pacific Region. In:Fermented Cereals, a Global Perspective. FAO Agriculure Services Bulletin No. 138(e-book).

Munroe J. H. (2006). Fermentation. In: Hand book of Brewing (F. G. Priest and G. G. Stewart eds.), pp.491-502. CRC press, London.

Prescott S. C. and Dunn C. G. (1959). Industrial Microbiology, 3rd Edn. McGraw-Hill Book Company, Inc. Newyork Toronto, London.

Prescott S. C. and Dunn C. G. (1987). Industrial Microbiology, 4th Edn. McGraw-Hill Book Company, Inc. New Delhi, India.

Phiarais B. P. N., Wijngaard H. H. and Arendt E. K.(2005). The Impact of Kilning on Enzymatic Activity of Buckwheat Malt. J. Inst. Brew. 111(3), 290-298.

Ranganna S., (2001).Handbook of Analysis and Quality Control for Fruit and Vegetable products, 2nd edn, Tata McGraw-Hill Publication., New Delhi.

Sharma K. P., Dahal K. R. and Batsa B. K. (1994). Genetic diversity of Nepalese Naked Barley and possibility of yield improvement. In: Proceedings of National Conference on Science. and Tech., 2, pp. 231-237, NAST, Kathmandu, Nepal.

Stewart G. G. and Russell (1987). Modern Brewing Technology. In: Comprehensive Biotechnology, vol-3. (Murraymoo-Young, ed-in-chief), pp. 335, Pergamon Press., Oxford, New York, Toronto, Sydney, Frank Furt.

Tiwari M. P. (2010). To study brewing quality of different Nepalese finger millet (Eleucina coracana). Dissertation M. Tech. (Food), CCT, TU, Dharan, Nepal.

Tsuyoshi N.,Fudou R., Yamanaka S., Kozaki M., Tamang N., Thapa S., Tamang J. P. (2005). Identification of Yeast Strains Isolated from Marcha in Sikkim, a Microbial Starter for Amylolytic Fermentation. Int. J. Food Microbiol., 99:2, 135-146.

Wijngaard H. H., Ulmer H. M., Neumannand M. and Arendt E. K. (2005). The Effect of Steeping Time on the Final Malt Quality of Buckwheat. J. Inst. Brew., 111:3, 275-281.

Zoecklein B. W., Fugelsang K. C., Gump B. H and Nury F. S. (1997). Wine analysis and Production, 1st edn., pp. 411-414, CBS Publishers and Distributors 4596, 1-A, 11 Darya Ganj, New Delhi- 110002, India. 